\title{
Proces a důsledky vymístování občanů ze sféry institucionalizovaného občanství v důsledku normativního tlaku expertní kultury
}

\author{
Magdaléna Jantulová
}

Angelika Bammer ve svém úvodu ke knize Displacement (1994) poukazuje na dva možné významy pojmu ,vymístění“ vzhledem k žitým zkušenostem, které vymístění reprezentují. Jednou z forem vymístění je oddělení jedinců od jejich kultury. Bammer (1994) mluví hlavně o oddělení fyzickém, které má formu vysídlení či vyhnanství z určitého prostoru i kultury. Jedná se o uprchlíky, emigranty atd., kteří jsou s př́íchodem do jiné geografické oblasti nuceni přizpůsobovat se místní kultuře.

Vymístění z určité kultury probíhá dle Bammer (1994) také formou kolonizaci kultury jinou kulturou. Jedinci jsou nuceni přjímat pravidla a hodnoty kolonizující kultury a musí se vzdát své původní kultury. Tato forma vymístění jedinců se liší od výše zmiňované tím, že probíhá na symbolické úrovni.

Předmětem zájmu této stati jsou konsekvence vymístění občanů z veřejného prostoru v důsledku sílícího vlivu normativního tlaku expertů a expertního vědění v moderní společnosti. Zaměřím se hlavně na způsoby a reprodukci vymíst’ování občanské kultury kulturou expertní a na možné důsledky potencionálního či aktuálního vymíst’ování na potenciál občanské participace.

\section{Povaha moderní veřejnosti}

Moderní veřejnost ve svém ideální modelu, tak jak ji prezentuje Habermas (2000b), charakterizují dva normativní standardy. Prvním z nich je její principiální otevřenost. Do veřejného prostoru má př́istup každý občan bez rozdílu původu, náboženství atd. Platí zde univerzální pravidla, která otevřenost této sféry zajišt'ují. Princip otevřenosti ovlivňuje také podobu a jednání institucí, které se ve veřejném prostoru formují. Zadruhé, přítomnost jedinců vycházející ze svobodného rozhodnutí je dobrovolná. Univerzálnost veřejnosti je dle Habermase omezena jen jedním prvkem, a to jazykem. Moderní veřejnost byla konstituována na základě diskusí k projednávaným záležitostem a diskurzivního hledání shody mezi aktéry. Aby společná diskuse mohla probíhat, bylo zapotřebí používat jazyk, který by byl srozumitelný pro všechny aktéry. Jazyk, který se začal k tomuto účelu využívat, měl národní charakter a na základě toho získal také veřejný prostor národní povahu. 
Aktéři, kteří tvoří moderní veřejnost, mají status občanů. Talcott Parsons (1971) v konceptu „společnostní komunity“ poukazuje na to, že moderní občanství má dvě rozdílné roviny. Občanství je určováno jednak zákony národních států. Právní předpisy vytyčují podmínky, na základě kterých se stávají jedinci občany, a dále slouží zároveň jako zdroj sebeuvědomění občanů. Tento typ občanství však má do jisté míry nedobrovolný charakter. Jedinec se nestává občanem na základě své dobrovolné volby, ale na základě úředního uznání.

Druhá rovina moderního občanství je dle Parsonse (1971) formována v rámci aktivní participace ve veřejném prostoru. Občanem se jedinec stává, pokud je ochoten a schopen podílet se na diskurzivním hledání shody nezávisle na státní autoritě. Může se jednat jak o přímou participaci na veřejné komunikaci, tak také o realizaci takových činností, které přispívají k veřejné diskusi (Habermas 2000a).

Občanství je ve zkušenosti moderního člověka reprezentováno různými diskurzivními a symbolickými zpo̊soby. Jeffrey Alexander (1998) vytvořil teoretickou a systematickou rekonstrukci symbolických kódů občanské kultury, které představují hodnotovou reprezentaci občanství v moderní společnosti.

Pro institucionální úroveň jsou dle Alexandra (1998) charakteristické občanské kódy, jako jsou pravidla (vs. arbitrárnost), zákon (vs. moc), rovnost (vs. hierarchie), inkluze (vs. exluze), neosobní vztahy (vs. osobní vztahy), smluvní vztahy (vs. askriptivní loajalita), sociální skupiny (vs. frakce), úřad (vs. osobnost). Protikladem k těmto občanským kódům jsou ,proti-občanské kódy“. Tyto dva typy kódů Alexander (1998: 101) představuje v následujícím schématu:

\section{SCHÉMA 1}

\begin{tabular}{|l|l|}
\hline občanský kód & proti-občanský kód \\
\hline pravidla & arbitrárnost \\
\hline zákon & moc \\
\hline rovnost & hierarchie \\
\hline inkluzivní & exkluzivní \\
\hline neosobní & osobní \\
\hline smluvní vztahy & askriptivní loajalita \\
\hline sociální skupiny & frakce \\
\hline úřad & osobnost \\
\hline
\end{tabular}

Tyto kódy lze uplatnit pro hodnotovou interpretaci vztahů a činností. Pomocí těchto kódů je možno rozlišit občanskou a neobčanskou kulturu, která ovlivňuje jednání jedinců, a dále na jejich základě určit neobčanské typy institucí, tj. ty, v rámci kterých nejsou uplatňovány hodnoty moderního občanství.

Občanská kultura je považována za jeden z důležitých faktorů, které mají vliv na potenciál občanské participace ve veřejném prostoru. Je mnoho dalších faktorů, které ovlivňují zájem občanů participovat ve veřejném prostoru, jako např́klad formálně institucionální prostředí, v rámci kterého jedinci jednají, sociální předpoklady nebo individuální dispozice aktérů. V současnosti se však formálně institucionální podmínky pro participaci občanů ve veřejné prostoru, určené na základě zákonů a deklarací, v Evropě a Americe téměř nemění. Co se však mění, jsou kulturní předpoklady (Habermas 2000a). K jedné z takovýchto změn dochází v rámci stále většího rozmachu expertní kultury. 


\section{Expertní kultura}

Se stálým zvětšováním objemu odborného vědění a s jeho postupným rozšiřováním do všech sfér sociálního života, roste v moderní společnosti i vliv vědy a jejího produktu - odborného vědění (Stehr 1994). Odborné vědění postupně vymístuje ze sociálního života všechny další formy vědění a stává se zdrojem moci a vlivu a také důležitým stratifikačním prvkem. Autorita a sociální pozice se ve společnosti, jak uvádí Stehr (1994), odvozují od množství a povahy vědění a jsou dále potvrzovány v rámci sociálních vztahů mezi těmi, kteří vědění vlastní a těmi, kteří $\mathrm{k}$ vědění nemají př́istup.

S novým zdrojem moci se také mění typ aktérů, kteří mají ve společnosti moc. Jedná se hlavně o experty a poradce, kteří mají odpovídající odborné vědění a ovládají zdroje vědění. Experti jsou, dle Stehra (1994: 75), ,tlumočníky a zprostředkovateli mezi vědou a subjektivními potřebami jedinců a mezi objektivním a subjektivním“.

Pro experty je charakteristické, že sami určují a legitimizují charakter a pravidla své činnosti, a to na základě svého specializovaného vědění. Jsou chráněni normami a pravidly, které vymezují, co je považováno za expertní vědění, a vylučují tak každého, kdo nemá kvalifikaci pro př́istup k němu (Stehr 1994). Tyto normy nevychází dle Habermase (2000a) z nezobecnělých zájmů, ale zakládají se na násilí. Jsou protipólem k normám, které vyjadřují zobecnělé zájmy, jež vznikaly na základě konsensu prostřednictvím participace občanů na diskurzivních procesech utváření jejich vůle. Expertní normy nevyžadují žádnou jinou legitimizaci, protože samy o sobě jsou jako legitimizační premisy dostatečné. Jak uvádí Niklas Luhmann (in Habermas 2000a: 125), „... právo se dodržuje proto, že je ustanoveno oprávněným rozhodnutím podle určitých pravidel“". Odpovědnost za platné právo pak nesou instance, které jsou předem ustanoveny, vybaveny kompetencemi a uznány za kompetentní, uvádí Luhmann.

Posilování významu expertního vědění ve společnosti se pojí se zvětšováním závislosti těch, kteří expertní vědění nemají, na těch, kteří odpovídající vědění mají. Habermas (Giddens 1998: 129) mluví v této souvislosti o kolonizaci životního světa abstraktními systémy. Vlivem manipulace expertů s podmínkami sociální existence dochází k tomu, že osobní rozhodnutí jedinců se podřizují odborné autoritě vědění.

Důležitou otázkou je také způsob reprodukce sociálního řádu konstituovaného na základě expertního vědění. Dle Baumana (in Stehr 1994) „expertíza vytváríi potřebu sebe samé“. Ospravedlňuje svou potřebu tak, že poukazuje na stále nové a nové problémy, které je třeba řešit. Každé řešení problému pak přináší další problém. Tento trend sebelegitimizace dle Baumana (in Stehr 1994: 94) úzce souvisí se stále populárnějším komerčním sloganem: „všechno co děláš, můžeš dělat lépe“. Expertům se daří udržet svou specifickou pozici ve společnosti také díky nemožnosti sociální kontroly jejich aktivit jinými aktéry než opět experty. Některé aktivity se tak dostávají mimo veřejnou kontrolu a laická veřejnost se ocitá pod kulturní a intelektuální kontrolou expertů (Turner 2003: 21).

\section{Expertní normy}

Pro expertní institucionální rámec jsou charakteristické tři základní normativní standardy (Parsons 1939). Jedná se o racionalitu, funkční specificitu a universalismus. 
Racionální charakter institucionálního modelu souvisí s rozvojem aplikace vědy v moderní společnosti. Racionalita není dle Parsonse něco, co by bylo člověku ,přirozené“, nýbrž má institucionální povahu. Je normativním modelem, který je nezávislý na tradičních soudech vycházejících z praktických zkušeností, je (naopak) konstruován na základě vědeckého zkoumání a je postaven na expertním vědění, jež má charakter vnitřního konzistentního systému - teorie.

Jako druhý obecný prvek institucionálního modelu uvádí Parsons způsob, jakým experti využívají svou společenskou autoritu. „Expertní autorita má zvláštní sociologickou strukturu. Není založena na obecném vyšším statusu, tak jako autorita bílého muže vůči černochovi; je založena na vyšších ,technických kompetencích expertů‘ “ (Parsons 1939: 38). Z toho však také vyplývá, že autorita je limitována jen na oblast daných technických kompetencí, a tak je dle Parsonse charakteristická svou „funkční specificitou“.'

Parsons dále upozorňuje na to, že „funkčně specifické technické kompetence jsou jen jedním typem případů, v nichž je funkční specificita základním elementem moderního institucionálního modelu“. Funkční specificita např́iklad ovlivňuje také podobu ,smluvních vztahư“ aktérů. Vztahy, práva a závazky mezi experty a ne-experty jsou determinovány rozdílnými technickými kompetencemi, znalostmi a dovednostmi a jsou proto funkčně specifické. ${ }^{2}$ Parsons uvádí příklad vztahu lékaře a pacienta. Osobní otázky, které klade lékař pacientovi, jsou legitimizovány tím, že jsou důležité pro specifickou funkci lékaře, který potřebuje informace ke stanovení diagnózy. Stejně jako v př́ípadě racionality upozorňuje Parsons na to, že funkční specificitu nelze brát za obecný, ,přirozený“ základ akcí jedinců.

Standardy a kritéria, na základě kterých se vztahy expertů a ne-expertů (jejichž častější označení je také „,klient“ či „,prrípad“) formují a organizují, mají také univerzální charakter. ${ }^{3}$ Vztahy mezi experty a ne-experty, jak uvádí Parsons, jsou klasifikovány nikoli na základě kritérií, které se od aktéra k aktérovi liší, ale na základě „objektivních“ a univerzálních kritérií, které jsou nezávislé na jednotlivých osobních vztazích. Univerzální kritéria upravují nejen vztahy mezi aktéry; jsou také základem pro jejich rozhodování a legitimizaci jejich jednání. Avšak vzhledem k tomu, že vycházejí z jejich specifického vědění, platí jen v oblasti zaměstnání, ne již v oblasti primárních vztahů (Parsons 1939: 42). Jejich univerzální povaha zaručuje emoční neutralitu vztahů. Instituce expertů je tedy dle Parsonse charakterizovatelná racionálností, univerzalismem a funkční specificitou. Hodnoty a normy, které ovlivňují jednání a vztahy aktérů, vychází nikoli z tradičního, ale z odborného vědění. Autorita je distribuována a legitimizovány jen v rámci limitované expertní oblasti a je regulována přijímáním univerzálních standardů. Od autority uplatňované v ostatních institucích - např́klad v rodině či v rámci přátelství - se liší tím, že zde nepřevládá univerzalismus, ale spíše partikularismus, a role aktérů jsou spíše funkčně difúzní než specifické.

\section{Normativní vliv expertů}

Experti jsou dle DiMaggia a Powella (1983) jednou z dominantních normativních autorit moderní společnosti. Normy a standardy, které definují, kontrolují a legitimizují, ovlivňují nejen jejich jednání, ale i jednání dalších aktérů ve společnosti. Normativní rámec expertní kultury se tak i pro ostatní aktéry - ne-experty - stává racionálním a správným. 
DiMaggio a Powell (1983) na základě výzkumů vysvětlují, jak je expertní normativní model prosazován v moderní společnosti. Zaprvé, expertní normativní model je podporován formálním vzděláním a legitimizován věděním, jenž je produkováno univerzitními specialisty. Univerzity a instituce zaměřující se na profesní výcvik jsou místem, kde jedinci dostávají nejen formální vzdělání, ale také místem, kde vznikají a reprodukují se normy a pravidla, jež regulují jednání expertů a vztahy mezi experty a laiky. Profesionálové, kteří se v rámci svého vzdělávání těmto normám učí, (Perrow in DiMaggio a Powell 1983), tvoří skupinu vzájemně zaměnitelných jedinců.

Zadruhé, ve společnosti roste počet a vliv profesních sítí, které spojují stále více organizací a aktérů. $\mathrm{V}$ rámci těchto sítí dochází k rozšiřování profesních norem a pravidel, k vytváření tlaku na aktéry směřujícímu k tomu, aby dané normy dodržovali, a k jejich sankcionování, pokud se tak nestane.

S rozšiřováním hodnot a norem v rámci pracovní činnosti expertů dochází dle DiMaggia a Powella k homogenizaci organizační kultury jednotlivých organizací, ve kterých tito experti působí. K homogenizaci přispívá také stále významnější fluktuace zaměstnanců - expertů a dále standardizace kritérií pro přijímání nových pracovníků. Noví pracovníci jsou například vybíráni na základě jasně stanovených kritérií, jako jsou typ vzdělání, chování, slovník atd. To má vliv na typ aktérů, kteří do organizace přicházejí. Aktéři, vybraní na základě shodných kritérií, (Kanter in DiMaggio a Powell 1983), vidí věci podobným způsobem, mají podobnou politiku, organizační styl, dělají podobný typ rozhodnutí. Důvodem však nebývá jen socializace v rámci stejné profesní kultury, ale také snaha o získání prestiže v rámci dané profese. Proto, aby prestiže dosáhli, je pro ně výhodné využívat homogenizované prostředky jednání.

\section{Vymísłování občanů experty z aktivní participace}

V další části textu budu demonstrovat proces a konsekvence vymístění občanů z veřejného prostoru v důsledku sílícího vlivu expertů a vědeckého vědění na příkladech změn odehrávajících se v nestátních neziskových organizacích v postkomunistických zemích na počátku 21. století. Nestátní neziskové organizace jsem zvolila proto, že právě tyto organizace se staly v postkomunistických zemích reprezentanty nezávislého, kompetentního, sebevědomého, odpovědného a veřejně aktivního občanství (více viz Marada 2003). Zdrojem dat budou případové studie pěti neziskových organizací s celorepublikovým působením, které patří k jedněm z nejvýznamnějších tvưrců a reprezentantů českého neziskového sektoru. ${ }^{4}$

Nejdříve se zaměřím na proměnu aktérů, kteří tvoří a reprezentují neziskové organizace, a na změny, ke kterým dochází v souvislosti s prríchodem nových typů aktérů, a to hlavně expertů, do neziskových organizací. Poté se budu věnovat vzniku a charakteru nových sociálních občanských rolí v souvislosti s prosazování normativního rámce expertní kultury.

\section{Proměna aktérů}

Typickými aktéry českého neziskového sektoru na začátku 90. let minulého století byli dobrovolníci. Ti ve svém volném čase bez nároků na honorář realizovali různé typy aktivit. Rozhodujícím kritériem pro jejich participaci byl jejich zájem. Postupem času, v důsledku 
sílícího vlivu expertů, pod tlakem státu a donorů, se v těchto organizacích objevuje nový typ aktérů - experti a profesionálové. Tito aktéři se od dobrovolníků liší tím, že pobírají za svou práci finanční odměnu, realizují ji nikoli jako dobrovolníci ve volném čase, ale v rámci určené pracovní doby jako svou pracovní činnost, na které jsou finančně závislí. Jsou přijímáni do organizací pro své odborné kompetence. Organizace také čím dál častěji využívají experty pro realizaci jednorázových specializovaných činností. Tito aktéři se nestávají členy ani zaměstnanci organizací, ale pouze externími spolupracovníky.

Experti realizují specializovanou činnost, která odpovídá jejich vzdělání a zkušenostem a je vymezena ve smlouvě, ne již další aktivity, které jsou např́klad v organizaci aktuálně potřeba. Ti experti, kteří pro organizaci pracují externě, neparticipují většinou ani na administrativní činnosti ani na demokratických procesech organizace. V souvislosti s tím dochází k interní diferenciaci organizace na jednotlivé specializované oblasti a k dělbě práce založené na principu funkčně specifické technické kompetence, tak jak je charakteristická pro expertní institucionální model (viz Parsons 1939).

Růst diferenciace rolí pracovníků s sebou prrináší potřebu formalizace pravidel i kontroly. Pravidla dostávají psanou formu a již se tak neodvíjejí od osobních vztahů či konkrétních situací, ale mají spíše univerzální charakter. Na jedné straně umožňují tato univerzální pravidla podílet se na činnosti organizace jedincům i krátkodobě, bez dřívějších zkušeností s činností v organizaci a nezávisle na individuálních zkušenostech jednotlivých aktérů. Na straně druhé, činnost aktérů tak získává čím dál více instrumentální a formální charakter.

Diferenciace organizační struktury je také úzce spojena s hierarchizací. Mezi jednotlivými aktéry dochází ke vzniku nerovností, které jsou dány rozdílnými odbornými kompetencemi expertů a dobrovolníků. Dobrovolníci mohou čerpat převážně jen z vlastní zkušenosti, což má v porovnání s vědeckým věděním menší význam. Nerovnosti jsou patrné již v samotném rozdělení pozic v organizaci. Experti jsou v pozicích, které jsou mocensky významné, jako je vedení projektu či organizace, zajištování zisku a kontrola financí, právní záležitosti atd. Z některých nových specializovaných oblastí činností dobrovolníky dokonce zcela vymíst’ují do role pasivních členů (to se týká např́íklad fundraisingu, ekonomiky atd.).

\section{Normativní vliv expertů}

S příchodem těchto nový členů - expertů - nedochází jen k etablování určitých organizačních forem, ale i k prosazení nových hodnot a norem. Tito aktéři přinášejí do organizace nové strategie jednání, metody činnosti, ale i hodnoty, které získali během svého vzdělání a v rámci předchozích zaměstnání jak v neziskových, tak také tržních či státních organizacích. Rozdílný normativní i kognitivní rámec, který experti uplatňují v rámci své činnosti v organizaci, má vliv na charakter aktivit, ale i kulturu a cíle organizace. Jejich vliv je o to významnější, protože, jak již bylo řečeno, zastávají v organizacích mocensky významné pozice a jsou na základě svého specifického vědění obecně považováni za autoritu.

Rozdílnost hodnot a cílů „nových“ aktérů - expertů - se projevuje mimo jiné vznikem konfliktů mezi „starými“ členy - dobrovolníky - a experty v rámci každodenních aktivit fungování organizace. Tuto situaci popisuje následující př́iklad. 
Ekologická nezisková organizace se rozhodla připravit novou strategii sebeprezentace na veřejnosti, získávání nových finančních zdrojů, organizace a řízení. Protože nikdo ze stávajících členů organizace se necítil být pro tento úkol kompetentní, byl přijat expert, který měl odpovídající vzdělání a pracovní zkušenosti v potřebné oblasti. Tento člověk nikdy v dané organizaci nepracoval ani s ní nespolupracoval a neměl žádné osobní kontakty s žádným ze členů organizace. Jak sám uvádí, po nástupu do této práce neznal dobře poměry v organizaci a až postupem času, poté, kdy měl možnost organizaci poznat, změnil určité své názory na ni a na strategie svého jednání.

Tento expert připravil návrh kampaně, jejíž součástí byla také prezentace organizace na veřejnosti. Expert určil jako vhodné metody prezentace např́ílad TV spoty a bilbordy, které považoval za nejúčinnější. „Staří“ členové organizace však jím navrhované metody nepovažovali za vhodné, protože byly v rozporu s hodnotami a posláním celku organizace i jednotlivých dobrovolníků.

Již samotný charakter kampaně, jež byla zaměřena na sebeprezentaci organizace a jež se měla stát samostatným projektem, nebyla v souladu s posláním organizace. Organizace si kladla za cíl aktivně se podílet na řešení celospolečenských problémů $\mathrm{v}$ oblasti životního prostřed a ne propagovat své aktivity a sebe sama. V rámci nové strategie získávání finančních zdrojů byly též prezentovány jiné ekologické organizace, které byly doposud vnímané jako partnerské a $\mathrm{v}$ mnohých případech také na různých projektech spolupracovaly, jako potenciální konkurenti, nebot' usilují o finanční prostředky na podobné aktivity.

V organizaci proběhla o těchto a dalších otázkách diskuse, v rámci níž vznikly dvě skupiny. Jedna skupina členů zásadně nesouhlasila s navrhovanou strategií a byla dokonce rozhodnuta z organizace odejít, pokud by se navrhované strategie začaly realizovat. Druhá skupina byla ochotna novou strategii přijmout, protože její zástupci experta vzhledem k jeho znalostem a zkušenostem považovali za autoritu.

Vzhledem k odbornému charakteru úkolu se však všechny reakce dobrovolníků omezovaly pouze na souhlas či nesouhlas, protože dosavadní členové neměli odpovídající znalosti k tomu, aby vytvořili protinávrh, a jejich zkušenosti byly nedostatečné.

$\mathrm{V}$ rámci celoorganizační diskuse byla pak upřednostněna strategie postupného rozvoje organizace v souladu s hodnotami a cíly organizace, potažmo starých členů, a zamítnuta potencionálně efektivní strategie, která by však byla v protikladu s prvotními hodnotami a cíli.

Na tomto př́ípadu je patrné, že prríchod expertů, kteří jsou přijímáni na základě specifického vědění a jež mají tendenci následně aplikovat své univerzální postupy a pravidla bez ohledu na poslání a hodnoty „starých“ členů, může být zdrojem potenciálního konfliktu. Problémem zde je, že expertní hodnoty a pravidla mnohdy nejsou slučitelná s posláním a hodnotami mnohých neziskových organizací. Vzhledem k obecné společenské autoritě expertů a expertního vědění a v souvislosti s tím vzhledem k nemožnosti kontroly expertů lidmi bez odpovídacího vědění, dochází spíše k prosazování expertního normativního rámce. I když, jak je patrné ve výše uvedeném prrípadě, nemusí tomu tak být vždy.

\section{Nové rozdělení rolí - vymístění dobrovolníků}

Př́itomnost expertů má vliv také na nové rozdělení rolí mezi jednotlivé typy aktérů. Dobrovolníci přesto, že jsou stále formálně součástí organizace a ze statistik vyplývá, že tvoří početně stále největší část aktérů, zastávají významně jiné role a realizují jiné typy aktivit než experti. Jedním z hlavních faktorů, který determinuje rozdělení rolí, již není zájem jedince o danou činnost, ale technická kompetence, která odpovídá povaze dané role. Přibývá tak počet dobrovolníků, kteří jsou členy organizace, ale neparticipují na demokratických procesech jako je příprava a strategické rozhodování o cílech a realizovaných aktivitách, a účastní 
se spiše jednorázových úkolů, které jsou jim určeny experty. Dobrovolníci si vybírají, na jaké akci se chtějí podílet a jakým způsobem, ze seznamu aktivit, který je každý týden připravován zástupci projektů. Tato nabídka je dobrovolníkům rozesílána nejčastěji e-mailem.

Dobrovolníci považují své role, které mají v organizaci (respektive, které jsou jim přidělovány), za adekvátní vzhledem ke svým kompetencím. Uvádí, že ve srovnání s experty a profesionály nemají odpovídající znalosti, zkušenosti ani dostatek času, který mohou práci v organizaci věnovat. Profesionálové se domnívají, že zapojení dobrovolníků do činnosti organizace určují a limitují jejich znalosti a zkušenosti. Je patrné, že v organizacích tak ubývá prostor pro amatéry, kteří nemají odpovídající vědění. Naopak dobrovolníci, kteří mají expertní znalosti a zkušenosti, které organizace potřebuje, se daleko rychleji integrují do činnosti organizace a jejich činnost není omezena jen na plnění zadaných úkolů.

Experti vidí limity činnost dobrovolníků také v jejich zájmu. Uvádí, že dobrovolníci nemají vždy zájem participovat na všech aktivitách, které jsou potřebné pro fungování organizace, a dále nechtějí přebírat zodpovědnost za realizaci náročnějších projektů. Sami si dle expertů volí aktivity, které jsou omezeny jen na plnění jednoduchých úkolů. V neposlední řadě je dle expertů limitem i čas, který dobrovolníci mohou věnovat činnosti v organizaci. Dobrovolníci realizují své aktivity tehdy, když mají čas, ne když je třeba určitý úkol splnit. Naopak experti vzhledem k tomu, že jsou na své práci závislí, a to jak finančně, tak v souvislosti s rozvojem své profesní kariéry, vykonávají aktivity pravidelně.

Porovnáme-li výpovědi dobrovolníků a profesionálů, je patrné, že „nezájem“ dobrovolníků, jak jejich jednání interpretují experti, vychází z omezování možností participace, v důsledku růstu významu odborného vědění. Participanti dále ztrácejí důvěru ve vlastní schopnosti a zkušenosti ř́́dit a správně zvládat mnohé aspekty svého života a orientovat se a participovat na záležitostech veřejného zájmu, protože nemají odpovídající odborné vzdělání. V důsledku se zmenšuje množství osobních vkladů, které jsou ochotni vynaložit, na úkor pouhého plnění zadaných úkolů a jsou daleko méně identifikováni s danou organizací. Zodpovědnost za realizaci cílů přenechávají profesionálům, a to nejen proto, že mají dle jejich názoru pro práci lepší kompetence, ale také proto, že mají ve své pozici zaměstnance povinnost plnit formálně zadané úkoly.

Jedná se o podobnou situaci, kterou již Olson označil jako free-ride problém. Olson na základě svých výzkumů uvádí, že pokud aktéři získají odměnu bez prímé participace, stává se pro ně výhodnější se neangažovat a získat kolektivní zisk bez zapojení do kolektivní akce. ${ }^{5}$ Ve výše popisovaném př́padě dobrovolníci za zisk považují dosažení organizací deklarovaných cílů, a tím i dosažení svých zájmů, jako je např́klad ochrana životního prostředí či pomoc sociálně slabým. Pokud dobrovolníci získají zkušenost, že jejich cíle jsou dosaženy i bez jejich aktivní účasti a to tak, že je realizují profesionálové, vede to ke snižování potenciálu jejich občanské participace.

\section{Nové podoby participace - alternativa k vymístění}

Reprezentanti neziskových organizací si však uvědomují, že pro zajištění legitimity svých aktivit potřebují nejen experty s odpovídajícím věděním a prestiží ve společnosti požívající, ale také co nejširší podporu občanů. Proto čím dál častěji spoléhají nejen aktéry 
disponující expertním věděním, ale také na instituce pasivního členství. Organizace využívají převážně finančního, ne již sociálního a kulturního kapitálu občanů, tak jako tomu bylo dříve. Přijímají nové členy, kteří se však aktivně podílejí na aktivitách a rozhodování o strategiích fungování organizace jen v minimálním rozsahu. Jejich participace je většinou omezena pouze na poskytování finanční podpory ve formě členských př́spěvkủ. ${ }^{6}$ Jestliže dříve byla veřejná podpora projevována ve formě času stráveného realizací konkrétní akce a aktivního zájmu občanů, dnes se jedná spíše o podporu finanční. Tato forma participace je méně náročná, a tak jí využívá stále více občanů. Jak uvedu níže, přses svou nenáročnost může však i tato forma angažovanosti mít vliv na kultivaci občanských hodnot a dovedností.

Pasivní členové se nesetkávají s ostatními členy v rámci pravidelné spolupráce na společných projektech a nenavazují osobní sociální vazby s ostatními členy organizace. Nezískávají tak zkušenost ze spolupráce s ostatními lidmi, se kterými by sdíleli společné zájmy. Nevytvárí se mezi nimi osobní sítě důvěry, které jsou důležitým zdrojem motivace pro další participaci, a nedochází ke kultivaci občanských hodnot. Tito aktéři daleko méně rozumějí názorům druhých, jeví se být daleko méně tolerantní a senzitivnějšś k potřebám ostatních a jsou méně ochotni měnit své názory. ${ }^{7}$ Nemají možnost kultivovat své občanské dovednosti jako je komunikace, organizace veřejných akcí atd.

Jak jsem uvedla, „pasivni““ členové se nestávají součástí sociální sítě organizace. Jsou však s organizací propojeni sítěmi informačními. Všichni členové organizace jsou pravidelně informováni o činnosti organizace - o akcích, hospodaření, nebo mohou využívat servis, který organizace poskytují pro své členy ve formě odborných rad. Např́klad jedna ekologická organizace nabízí svým členům následující: „Třikrát ročně pro Vás zdarma vydáváme šestnáctistránkový Magazín. Najdete v něm podrobnosti o naší práci, abyste věděli, jak s Vašimi penězi nakládáme. Můžete si v něm přečíst rozhovory se známými osobnostmi, ekologické rady do domácnosti, recepty pro zdravý životní styl, tipy na výlety a podobně“ (z internetových stránek ekologické organizace).

Velkou roli při distribuci těchto informací dnes hrají nové technologie. Díky nim mohou neziskové organizace pravidelně a za minimálních nákladů distribuovat velké množství informací široké skupině lidí. Skrze tyto informace jsou distribuovány také hodnoty a pravidla a vytváŕí se virtuální interakce. Jedinec se tak může identifikovat $\mathrm{s}$ danou organizací bez osobního kontaktu. Je to však opravdu možné bez face-to face kontaktu? Teorie imaginární komunity poskytuje vysvětlení toho, jak může dojít k vytváření sociálního kapitálu bez př́mé interakce (Anderson 1991). Imaginární komunita je založena na abstraktních formách důvěry. Lidé, kteří jsou silně spojeni s imaginární komunitou národa, vyjadřují dle Whiteleye (1999) daleko větší důvěru v další občany jejich národa než jedinci, jejichž patriotismus je slabý.

Wollebaek a Selle (2002) uvádějí, že vztahy v imaginární komunitě, které jsou typicky spojovány se vztahy občana k národnímu státu, jsou srovnatelné se vztahy pasivních členů a neziskových organizací. Mnoho neziskových organizací je podobně jako národní stát sociálním systémem, který je již př́liš velký na to, aby umožňoval face-to-face kontakt všech svých členů. Členové neziskových organizací však stejně jako občané národního státu mohou sdílet hodnoty a závazky.

Př́ikladem toho, jak neziskové organizace utvářejí imaginární platformu sdílení hodnot, identifikace s organizací a důvěry je vytváření sdíleného vědění například skrze materiály distribuované pro členy klubu. Př́íkladem může být tento úryvek z materiálů jedné humanitární 
neziskové organizace: „Zveme Vás, abyste se stali členy společenství lidí, kteří souhlasí s věcným př́ístupem ke světu, založeným na slušnosti a spoluzodpovědnosti za řešení krizí a dlouhodobých problémů ve světě i u nás. Tedy s tím, že je svým způsobem povinností nás všech, žijících v relativním dostatku, stabilitě a jistotě, pomáhat lidem, kteří takové štěstí nemají.“

Informace, které organizace dobrovolníkům poskytují a jež jsou zdrojem sdíleného vědění, zkušeností, ale i idejí a hodnot, jsou tvořeny převážně experty. Sdílená kultura již není produkována širokou skupinou samotných členů v rámci veřejné diskuse, tak jak tomu je v rámci sociálních sítí, ale je tvořena experty a členy pouze pasivně přijímána. Občan se může pouze rozhodnout, zda danou organizaci podpoří či ne, tedy stane-li se součástí informační sítě organizace, v kteréžto pozici však nemůže již přímo ovlivňovat její podobu.

\section{Nový typ neziskových organizací}

V posledních letech jsme mohli kromě změny typů aktérů a jejich rolí v neziskových organizacích zaznamenat také rozvoj nového typu samotných neziskových organizací. Tyto organizace reprezentují určité zájmové skupiny, jejichž činnost je založena na vynášení expertních požadavků nebo kritizování jiných expertů, či jsou určitými zájmovými skupinami podporovány. Jsou tvořeny vždy jen malou skupinou expertů. Jedná se např́íklad o organizace Greenpeace, Arnika apod. Tyto zájmové organizace slouží veřejnému cíli. Prezentují se jako reprezentanti veřejnosti. Otázkou však je legitimita jejich aktivit.

\section{Konsekvence vymísfování}

$\mathrm{V}$ důsledku sílícího vlivu vědy a v souvislosti s tím i vědeckého vědění a osob expertu, které se rozšiřují do všech sfér moderní společnosti a tedy také do sféry institucionalizovaného občanství, je možno zaznamenat významný normativní tlak expertní kultury. Experti v rámci svého jednání uplatňují a ze své mocenské pozice prosazují normativní rámec expertní kultury a kolonizují ostatní kulturní rámce. Tento proces kolonizace probíhá také v rámci sféry institucionalizovaného občanství. Dochází ke kolonizaci občanské kultury a v souvislosti s tím také ke změně institucionálního uspořádání této sféry.

Základní hodnotou se stává odborné vědění. Občané, jejichž vědění vychází z každodenních praktických zkušeností a nemá vědeckou povahu, nejsou považováni, a také se nepovažují, za kompetentní aktéry jednání ve veřejném prostoru. Dochází k exkluzi všech aktivních participantů, kteří nemají odpovídající vědění. Jeden ze základních principů moderního občanství - inkluze - je nahrazován principem exkluze (viz Alexander 1998). S tím se mění i možné způsoby jednání a role, které jsou pro daný institucionální prostor charakteristické.

Autorita expertů je odvozována z charakteru vědění, který má jedinec k dispozici, a tímto věděním je také legitimizována. Jejich autorita se dále posiluje také proto, že zákony, které regulují jednání, jsou opět tvořeny a schvalovány experty. Jejich činnost může být ve společnosti organizované v termínech vědění kontrolována jen těmi, kteří odpovídající vědění mají a kteří dle Stehra (1994) mají k dispozici dostatek informací. Dobrovolníci pod tlakem expertní kultury přijímají role těch, kdo mají důvěřovat a ne kontrolovat. 
Také sociální vztahy jsou determinovány charakterem vědění. Mezi experty a občany-laiky nejsou vztahy organizovány na principu rovnosti, ale mají spíše hierarchický charakter, což je v rozporu s hodnotami moderního občanství (viz Alexander 1998). Patrné je to na př́kladu proměny rolí v rámci prostředí občanských aktivit. Experti zastávají mocensky významnější role než dobrovolníci. Dochází tak k omezování moci a autonomie dobrovolníků - laiků -, kterým je přisuzována spíše pasivní role, v rámci které jsou podřizeni expertům. Pro organizaci, která je řízena experty, vykonávají pouze servisní činnost, nebo se jejich participace omezuje na poskytování finančních prostředků na realizaci aktivit, o kterých rozhodují jiní - experti.

Jednání expertů vychází z vědeckých poznatků a je ř́zeno objektivními univerzálními pravidly, která nejsou aplikována nezávisle na jednotlivých osobních vztazích, a mají tak potenciál být emočně neutrální. Vytváření neutrálních vztahů, jejichž pravidla jsou stanovována experty a jež mají univerzální charakter, ovlivňuje charakter a tvorbu sociálních sítí př́tomných v organizacích. Sociální sítě, v rámci kterých jsou tvořeny a udržovány občanské hodnoty a posilován pocit sounáležitosti a důvěry, jsou nahrazovány sítěmi informačními. Do jaké míry mohou tyto informační sítě, které mají spíše vertikální než horizontální charakter, nahradit sociální sítě jak v oblasti tvorby a sdílení hodnot, tak ve vztahu k utváření důvěry mezi aktéry, je otázkou dalšího zkoumání.

Pod normativní tlakem expertní kultury se v neposlední řadě mění základní normativní vztahový rámec sebechápání a interpretace vlastního jednání; v souvislosti s tím dochází k oslabování sociální identity participujících občanů a k omezování aktivní participace a investování vlastního času. Občané, kterým je připisována a od nichž je očekávána role nekompetentních a pasivních aktérů, ztrácejí důvěru ve vlastní dispozice řídit a správně zvládat mnohé aspekty svého života a orientovat se v záležitostech života veřejného. Jak ovšem vyplývá např́iklad z výzkumů Almonda a Verby (1989), důvěra v subjektivní občanské kompetence je jednou z důležitých individuálních dispozic, které ovlivňují míru a charakter občanské participace.

\section{Poznámky}

1 Funkční specificita je charakteristická i pro další institucionální modely v moderní společnosti, jako např́klad pro administrativní „úřad“. Autorita však v tomto institucionální modelu není odvozena od technických kompetencí, ale je dána postavením jedince v hierarchii daného úradu. A je proto také limitována jen pro jeden daný úřad.

2 Opačný charakter než vztahy profesionálů mají dle Parsonse přátelské vztahy. Ty mají na rozdíl od specifického typu spíše difúzní charakter.

3 Opakem univerzalismu je partikularismus, v jehož rámci standardy a kritéria vztahů vycházejí ze vztahů osobních.

4 Jedná se o neziskové organizace s celorepublikovým působením v oblasti ekologie, humanitární činnosti, servisu pro neziskové organizace, lidských práv a sociální pomoci. Jako zdroje dat byly využity případové studie těchto organizací, které vznikly v rámci projektu „Organizační inovace a interaktivní média v neziskových organizacích ve Východní Evropě“, jehož realizátorem by David Stark. Další informace o výzkumu lze nalézt na internetové adrese: http://www.sociology.columbia.edu/people/faculty/stark/papers/innovation_media_ngos.pdf

5 Referuje o něm např́iklad Znebejánek (1997: 95-96). 
6 Na růst počtu pasivních participantů, jejichž účast se omezuje jen na „vyplňování šeků“ (v anglickém originále „the cheque-book participation“) poukazují např́iklad také Putnam (1995), Wollebaek a Selle (2004) a další. Jedná se např́klad o organizace jako je Amnesty International, Friends of the Earth, Greenpeace a další.

7 Jak uvádí Verba a kol. (1995: 529), „v demokracii založené na participaci se politické aktivity stávají mechanismem rozumění názorům druhých a stávají se senzitivnější k potřebám komunity i národa“.

\section{Literatura}

Anderson, B. 1991. Imagined Communities: Reflections on the Origins and Spread of Nationalism (revised). London: Verso.

Alexander, J. C.1998. Real Civil Society: Dilemmas of Institucionalization. London: Sage.

Almond, A. G.,Verba, S. 1989. The Civil Culture Revisited. Sage Publications.

Bammer, A. 1994. „Introduction.“ In A. Bammer (ed.) Displacements. Bloomington, Indianapolis: Indiana University Press.

Bauman, Z. 1994. „Life-world and Epertise: Social Production of Depondency.“ In N. Stehr, R. V. Ericson, The Culture and Power of Knowledge. Walter de Gruyter.

DiMaggio, J., Powell, W. W. 1983. „The iron cage revisited: institutional isomorphism and collective rationality.“ American Sociological Review, vol. 48: 147-160.

Giddens, A. 1998. Dísledky modernity. Praha: Slon.

Habermas, J. 2000a. Problémy legitimity v pozdním kapitalismu. Praha: Filosofia.

Habermas, J. 2000b. Strukturální přeměna veřejnosti. Praha: Filosofia.

Marada, R. 2003: „Občanský sektor a organizační identita.“ In C. Szaló, I. Nosál (eds.) Mozaika v rekonstrukci. Formování sociálních identit v současné střední Evropě. Brno: IIPS.

Parsons, T. 1939. „The Professions and Social Structure.“ In T. Parsons Essays in Sociological Theory. The Free Press of Glencoe.

Parsons, T. 1971. The System of Modern Society. Englewood Cliffs, N. Y.: Prentice-Hall, inc. Stehr, N., Ericson, R. V. 1994. The Culture and Power of Knowledge. Walter de Gruyter.

Turner, S., P. 2003. Liberal democracy 3.0: Civil society in an age of experts. London: Sage.

Verba, A. 1995. Voice and Equality: Civic Voluntarism in American Politics. Cambridge: Harvard University Press.

Whiteley, P. F. 1999. „The origins of social capital.“ In J. W. van Deth, M. Maraffi, K. Newton, P. F. Whiteley (eds.) Social Capital and European Democracy. London: Routledge.

Wollebaek, D., Selle, P. 2002. „Does Participation in Voluntary Associations Contribute to Social Capital? The Impact of Intensity, Scope, and Type." Nonprofit and Voluntary Sector Quarterly, vol. 34 (1): 32-61.

Znebejánek, F. 1997. Nová sociální hnutí. Praha: Slon.

\section{Autorka}

Magdaléna Jantulová působí jako odborná asistentka na Fakultě humanitních studií na Karlově univerzitě v Praze. V rámci doktorandského programu oboru sociologie na Fakultě sociálních studií Masarykovy univerzity v Brně v současnosti zpracovává svou disertační práci věnovanou profesionalizaci neziskového sektoru. Kontaktní e-mail: jantulov@fss.muni.cz 